\title{
Öğretmen adaylarının uzaktan eğitim ve öğretmenlik uygulaması dersine ilişkin görüşleri
}

\author{
Opinions of pre-service teachers on distance education and \\ teaching practice course
}

\section{Sibel Güven ${ }^{1}$ \\ Merve Uçar²}

1 Doç. Dr. Çanakkale Onsekiz Mart Üniversitesi, Eğitim Fakültesi, Temel Eğitim Bölümü, Çanakkale, TÜRKiYE, e-mail: s_guven@comu.edu.tr 2 Doktora öğr., Çanakkale Onsekiz Mart Üniversitesi, Eğitim Fakültesi, Temel Eğitim Bölümü, Çanakkale, TÜRKiYY, e-mail: merveucar7@gmail.com

\begin{abstract}
Öz
Dünya çapında etkili olan ve her alanda olumsuz etkilerini göstermeye devam eden COVID-19 salgınının neden olduğu yayılım, yükseköğretimde de olumsuz etkilerini göstermiş ve uzaktan eğitime acil bir geçiş yapılmıştır. Uzaktan eğitim ile, eğitim fakültelerindeki öğretmen adayları, uygulamalı dersleri teorik şekilde görmeye başlamıştır. Temeli uygulama olan öğretmenlik uygulaması dahil olmak üzere devam eden eğitim ve öğretim faaliyetleri, çevrimiçi şekilde sürdürülmekte ve bu ilerleyişin öğrenciler üzerinde bıraktığı izlenim, olumlu veya olumsuz yanları, sürecin hızlı ve hazırlıksız olmasından dolayı değerlendirilememiştir. Bu araştırma ile salgıni sürecinde uzaktan eğitim ve öğretmenlik uygulamalarına ilişkin öğretmen adaylarının görüşlerinin alınması ve değerlendirilmesi amaçlanmıştır. Araştırmada, nitel yöntem desenlerinden olan durum çalışmasından yararlanılmıştır. Toplanan veriler içerik analizi tekniği ile analiz edilmiş, veri analizinde MAXQDA 2020 paket programı kullanılmıştır. Araştırmanın çalışma grubunu, bir devlet üniversitesinin eğitim fakültesinde öğrenim görmekte olan ve aynı zamanda uzaktan eğitim ile öğretmenlik uygulaması dersini alan öğretmen adayları oluşturmaktadır. Elde edilen bulgular doğrultusunda öğretmen adaylarının uzaktan eğitimi, derslerin işleniş şeklinden ve internet sorunları yüzünden yetersiz buldukları, öğretmenlik uygulamasının uzaktan eğitim ile sürdürülmesinin tecrübe açısından eksiklik yaratacağı sonuçlarına ulaşılmıştır. Araştırmada, uzaktan eğitimin iletişim yönünden ve sınıf ortamından uzaklık gibi eksiklikleri olduğu, öğretim elemanlarının ise bu süreçte yeterli görüldükleri sonuçları da yer almaktadır.
\end{abstract}

Anahtar kelimeler: uzaktan eğitim, öğretmenlik uygulaması, pandemi

\section{Abstract}

The pandemic caused by the COVID-19 epidemic, which is effective worldwide and continues to show its negative effects in every field, has also shown its negative effects in higher education and an urgent transition to distance education 
has been made. With distance education, teacher candidates in education faculties started to see applied courses in a theoretical way. Continuing education and training activities, including the teaching practice, which is based on practice, are carried out online, and the positive or negative aspects of this progress on students could not be evaluated due to the rapid and unpreparedness of the process. With this research, it is aimed to obtain and evaluate the opinions of teacher candidates regarding distance education and teaching practices during the pandemic process. In the research, case study, which is one of the qualitative method patterns, was used. The collected data were analyzed by content analysis technique, and the MAXQDA 2020 package program was used in data analysis. The study group of the research consists of teacher candidates who are studying at the faculty of education at a state university and who also take the course of distance education and teaching practice. In line with the findings, it was concluded that the pre-service teachers found distance education inadequate due to the way the lessons were taught and internet problems, and that the continuation of the teaching practice with distance education would create a lack in terms of experience. In the research, there are also the results that distance education has deficiencies in terms of communication and distance from the classroom environment, and the instructors are deemed sufficient in this process.

Keywords: distance education, teaching practice, pandemic

\section{GİRIŞ}

Dünya genelini derinden sarsan ve her alanda olumsuz etkilerini göstermeye devam eden salgın, eğitimde değişime ve dönüşüme neden olmuştur. Türk Dil Kurmu'na göre epideminin kıtalar arasında yayılarak birden fazla ülkeyi etkisi altına alması olarak tanımlanan salgın, bir hastalığın aynı anda yaygın şekilde görülmesidir (TDK, 2021). Günümüzde COVİD-19 olarak bilinen yeni tip Korona Virüs 'ün, başta ABD, İspanya, İtalya, Almanya, Birleşik Krallık, Fransa, Çin, Türkiye, İran, Rusya, Brezilya ve Belçika'da olmak üzere etkisi artarak devam etmekte ve dünya genelinde büyük kayılara neden olmaktadır (WHO, 2020). Bozkurt'a (2020) göre COVID-19 sonrasında dünyada yaşananlar yeni normal ve yeni paradigma meydana getirmiştir. Bunun da yeni bir dünya düzenini doğuracağını söylemek mümkündür. Ancak kısa vadede günü kurtarmak için yapılan yanlış uygulamalar, uzun vadede daha büyük olumsuzluklar şeklinde karşımıza çıkmaktadır (Coeckelbergh, 2020; Daniel, 2020).

Salgının dünya çapında meydana getirdiği krizin sağlık başta olmak üzere ekonomik, psikolojik, sosyal yaşam ve eğitim üzerindeki etkileri, yansımaları devam etmektedir ve ne zaman sonlanacağına yönelik olarak kesin bir veri bulunmamaktadır (Can, 2020). Salgın olumsuz etkilerini, her alanda olduğu gibi yükseköğretimde de göstermiş ve ortaya çıkan değişimlerden kaynaklanan yansımalar, öğretim süreci ve uygulama boyutunda hem eğitim faaliyetlerini ve hem de öğrencileri etkilenmiştir. Bunun sonucunda da hızlı kararların alınması gerekmiş ve yeni düzenlemeler ortaya çıkmıştır.

Salgın dönemi başladığında çoğu ülke okulları geçici olarak kapattığını duyurmuştur. Bununla beraber salgının, öğrencilerin \%91'inden fazlasını etkilediği ve yaklaşık 1,6 milyar gencin de bundan etkilendiği rapor edilmiştir (Miks \& McIlwaine, 2020). COVID-19'un eğitimde sebep olduğu krize hızlı bir çözüm getirmek için örgün eğitime göre yapılanmış üniversiteler, yüz yüze eğitimin yerine web tabanlı uzaktan eğitim ile dersleri ve programları sürdürmek amacıyla hızla çalışmalara başlamışlardır. Yükseköğretimde acil uzaktan eğitime geçiş aşaması olmuştur (Gewin 2020; Lau ve diğ., 2020). Salgının yayılma hızını azaltmak için ülkeler ve yerel yönetimler, ev hapsi, seyahat kısıtlamaları ve okul kapatma gibi önlemler almışlardır. Bu süreçle beraber milyonlarca çocuk, genç ve yetişkin, okullara ve üniversitelere gidememektedir. Giannini ve Lewis'e göre (2020) bu durum sonucunda öğrencilerin ilerleyen dönemlerde eşit eğitim almaları konusunda büyük zorluklar yaşanabilecektir.

Bu aşamada hem sürecin hem de krizin yönetilebilmesi adına YÖK hızlı bir biçimde harekete geçmiş ve öğretim sürecinin uzaktan eğitime dönüştürülmesi için kararlar almıştır (YÖK, 2020). Bu açıklamalarla beraber tüm öğretim kademelerinde yüz yüze eğitime ara verilmiştir. Bu süreçte uzaktan eğitime geçilmesi, yerel ve merkezi sınavların ertelenmesi ve öğrenci başarısını ölçme ve değerlendirmede web tabanlı sınavların devreye girmesi gibi kararlar alınmıştır. Bu kararlar sonucunda da örgün eğitime uygun olarak yapılandırılmış sistemin acil bir şekilde kriz yönetimi ile web tabanlı uzaktan eğitim sistemine dönüştürülmesi gerekliliği ortaya çıkmıştır (Özer Kaya ve Keskin, 2020).

Pandemi nedeniyle, Türkiye'de YÖK'ün aldığı kararlar şu şekilde özetlenebilir; 
- Yükseköğretimde eğitime 12 Mart 2020'de eğitime ara verilmiş,

- 23 Mart 2020 tarihinden itibaren 2019-2020 öğretim yılı bahar döneminin tamamen açık ve uzaktan öğrenme sistemi ile devam ettirilmesine karar verilmiştir,

- YÖK Dersleri Platformu tüm öğrencilerin erişimine açık hale getirilmiştir,

- YÖK Başkanlığı almış olduğu kararla pandemi nedeniyle ön lisans, lisans ve lisansüstü seviyede eğitim alan öğrencilerin talepleri doğrultusunda 2019-2020 eğitim öğretim yılı bahar döneminde kayıtlarını dondurabilmesine; tez savunma ve yeterlik sınavlarının ise denetlenebilir olma ve "kayıt altına alınmak şartıyla" video konferans gibi dijital imkanlar ile yapılabilmesine imkân vermiştir,

- Yükseköğretim kurumlarının neredeyse tamının önlisans ve lisans programları için de ara sınavlarını çevrim içi ortamda gerçekleştirmeye yönelik hazırlık yaparak çevrim içi sınav uygulama esasları yayınlamaya başlamışlardır.

YÖK tarafından alınan kararlardan sonra, tüm üniversiteler kendi kapasitelerinin elverdiği kadar çevrimiçi eğitime geçmişlerdir. Bu dönemde Türkiye'deki üniversitelerin büyük çoğunluğunu çevrimiçi eğitime hazırlıksız oldukları gözlemlenmiştir. Türkiye'de pek çok kişinin uzaktan eğitim anlayışının, öğretim elemanlarının dersinin videoya kaydedilip senelerce ayn videonun öğrencilere sunulduğu bir sistem olduğu bilinmektedir (Erkut, 2020). Yüz yüze eğitime ara verilen okullardaki örgün ve yaygın eğitim pandemiden etkilenen en büyük kamusal alanlardan biri olmuştur. COVID-19 oluşturduğu krizden, ekonomilerini korumaya çalışan devletler, dijital teknolojilerin kullanımı$\mathrm{n}$ benimseyen acil durum önlem paketlerini devreye koyarak eğitim sürecini devam ettirmeye çalışmışlardır (Agnoletto \& Queiroz, 2020). Dünyadaki eğitim sistemleri, halk sağlı̆̆ını koruma girişimlerinin bölümü olarak salgının yayılmasını kontrol altına almak amacıyla zorunlu kılınan kitlesel okul kapanışlarından sonra eşi görülmemiş bir zorlukla karşı karşıya kalmıştır (UNES$\mathrm{CO}, 2020)$

Çakın, Akyavuz ve Külekçi (2020), Covid-19 sürecinin eğitime yansımalarını öğretmen görüşlerini alarak incelemişlerdir. Araştırmada, öğretmenlerin veliler ve öğrencilerin öğrenme süreçleri ile sorunlar yaşadıkları, öğrencileri motive edici etkinlikler ile gelecek için teşvik etikleri sonuçlarına ulaşmışlardır.

Kürtüncü ve Kurt (2020), Covid-19 pandemi döneminde hemşirelik öğrencilerinin yasadıkları sorunların belirlenmesi amaçladığı araştırmada öğrencilerin çoğu hem teori hem de uygulamalı derslerinin uzaktan eğitim ile yetersiz olacağını, okulu dondurmayı düşünmedikleri ancak okulun uzayacağını düşündüklerini belirttikleri sonucuna ulaşıldı.

Serçemeli ve Kurnaz (2020), uzaktan eğitim ile muhasebe dersini alan öğrencilerin, uzaktan eğitime yönelik öz yeterliklerini ve uzaktan eğitime yönelik öğrenci görüşlerini incelemeyi amaçladığı çalışmasında, öğrencilerin uzaktan eğitim sistemini çok fazla benimsemedikleri, sistemin kullanımıyla ilgili öz yeterlik açısından herhangi bir problem yaşamadıkları görülmüştür.

Çevik ve Bakioğlu'nun (2020) yaptığ çalışmada, COVID-19 salgını sürecinde uzaktan eğitimde neler yaşandığı konusunda ortaokulda görevli Fen Bilimleri öğretmenlerinin deneyimlerini derinlemesine anlamaya çalışılması amaçlanmıştır. Araştırma bulguları doğrultusunda Fen Bilimleri öğretmenlerinin pandeminin ne olduğunu bilmedikleri ortaya çıkmıştır. Uzaktan eğitim sürecinde internet bağlantısı, öğrencilerle iletişim kurma, öğrencilerin derslere katılım oranının düşük olması ve okul yönetiminin baskısına maruz kalma gibi problemlere sahip oldukları tespit edilmiştir.

Karahan, Bozan ve Akçay'ın (2020) sınıf öğretmenliği lisans öğrencilerinin salgın sürecindeki çevrim içi öğrenme deneyimlerinin incelenmesini amaçladığ lışmada, senkron derslerin daha verimli olduğu, bazı öğrencilerin internet yetersizliklerine sahip olduğu sonuçları elde edilmiştir.

Salgın döneminde yükseköğretimde uzaktan eğitim uygulamalarına geçilmesiyle, derslerin teori ve uygulanması boyutunda öğrenciler eşit olmayan fırsatlardan kaynaklanan sorunlarla karşılaşmışlardır. Eğitim sürecinin gerektirdiklerini, çevrimiçi dersler her anlamda karşılayamamış ve bunun sonucunda eğitim- öğretim faaliyetlerindeki olumsuz yansımaları ve bunların asıl nedenlerini ortaya çıkarmak önem arz etmiştir.

\section{ARAŞTIRMANIN AMACI}

Salgın süreci okulöncesi eğitimden yükseköğretime kadar tüm eğitim öğretim faaliyetlerini olumsuz etkilemiş ve özellikle de uygulama boyutundaki derslerin 
çevrimiçi ortamdan yapılmaya çalışılması öğretmen adayları için zorluklar ortaya çıkarmıştır. Bu aşamada öğretmen adaylarının sürece yönelik değerlendirmeleri, acil şekilde geçilen bu sistemin aksaklıklarını ve olumlu yanlarını ortaya koyacaktır. Bu araștırma ile COVID-19 salgının neden olduğu pandemi sürecinde, yükseköğretimde çevrimiçi eğitim uygulamalarının, eğitim fakültelerindeki uzaktan eğitim sürecine ve öğretmenlik uygulamalarına yansımaları, öğretmen adaylarının görüşleri doğrultusunda belirlemek amaçlanmaktadır.

- Araştırmanın amacı doğrultusunda belirlenen alt amaçlar şu şekildedir;

- Öğretmen adaylarının uzaktan eğitim uygulamalarının etkililiğine ilişkin görüşleri nelerdir?

- Öğretmen adaylarının yüz yüze eğitim ve uzaktan eğitimin karşılaştırılmasına ilişkin görüşleri nelerdir?

- Öğretmen adayları uzaktan eğitimin olumlu ve olumsuz yanlarını nasıl değerlendirmektedir?

- Öğretmen adaylarının görüşlerine göre uzaktan eğitim uygulamalarında karşılaşılan eksiklikler nelerdir?

- Uzaktan eğitim sürecinde, öğretmen adaylarının öğretim elemanlarına yönelik değerlendirmeleri ne olmuştur?

- Öğretmen adayları, öğretmenlik uygulaması dersinin, kendilerini uygulama boyutunun mu yoksa teori boyutunun mu geliştirdiğine ilişkin görüşleri nelerdir?

- Öğretmen adaylarının öğretmenlik uygulamasının uzaktan eğitim ile yapılmasının olumlu ve olumsuz yönlerine ilişkin görüşleri nelerdir?

- Öğretmen adaylarının öğretmenlik uygulamasının nasıl bir içeriğe sahip olmasına yönelik görüşleri nelerdir?

\section{YÖNTEM}

\subsection{Araştırmanın Deseni}

Öğretmen adaylarının görüşleri doğrultusunda pandemi döneminde uzaktan eğitim uygulamalarının eğitim sürecine ve öğretmenlik uygulamalarına yansımalarının belirlenmesinin amaçlandığı bu çalışmada betimleme ve anlamların derinliğini ortaya çıkarması (Büyüköztürk vd. 2013) açısından nitel araştırma yöntemi kullanılmıştır. Araştırma, sınırlı bir sistemin derinlemesine betimlenmesi ve incelenmesi (Merriam, 2018) olarak tanımlanan durum çalışması şeklinde desenlenmiştir.

Bir veya birkaç duruma yönelik etkenler, durum çalışmasında bütüncül bir yaklaşım içerisinde araștırılır. Bu durumların ilişkili durumu nasıl etkiledikleri ve ilgili durumdan nasıl etkilendikleri üzerine derinlemesine araştırma yapılır. (Yıldırım ve Şimşek 2018). Creswell'e (2011) göre bu araştırmalar birden fazla kaynaktan veri toplanarak derinlemesine incelemenin yapıldı̆̆ çalışmalardır ve araştırmacılar incelenen duruma yönelik derin anlayış geliştirmek amacıyla farklı türlerden verilere gereksinim duymaktadırlar.

\section{2. Çalışma Grubu}

Bu araştırmanın çalışma grubunu 2020-2021 eğitim-öğretim yılında bir devlet üniversitesi eğitim fakültesinde öğrenim görmekte olan öğretmen adayları oluşturmaktadır. Araştırmaya pandemi döneminde uzaktan eğitim ile öğretmenlik uygulaması dersini alan 109 öğretmen adayı katılım göstermiştir. Katılımcıların cinsiyetlerine ilişkin bulgular Tablo 1'de sunulmuştur.

Tablo 1.Katılımcıların Cinsiyete Göre Dağılımları

\begin{tabular}{lcc}
\hline Cinsiyet & f & \% \\
\hline Kadın & 95 & 87.15 \\
Erkek & 14 & 12.38 \\
\hline Toplam & 109 & 100 \\
\hline
\end{tabular}

Tablo 1'e göre araştırmaya katılan 95 katılımcı kadın, 14 katılımcı ise erkek öğretmen adayından oluşmaktadır.

\subsection{Veri Toplama Araçlarının Hazırlanması}

Araştırmanın amacı kapsamında öğretmen adaylarından veriler yarı yapılandırılmış bir görüşme formu ile toplanmıştır. Form araştırmacılar tarafından hazırlanmış ve araştırmanın amacı ve alt amaçlarına yönelik olarak 11 sorudan oluşmaktadır. Soruların hazırlanmaS1 aşamasında önceden tahmin edilebilir veya evet veya hayır gibi kısa yanıt gerektiren sorular tercih etmek yerine açıklama yapmayı gerektiren sorulardan yararlanılmıştır. Sorularının hazırlanabilmesi için "pandemi sürecinde eğitim" "uzaktan eğitim" "yükseköğretimde çevrimiçi eğitim" gibi anahtar kelimeler kullanılarak li- 
teratür taranmıştır. Buradan hareketle görüşme formu oluşturulmuştur. Görüşme formunda, katılımcıların uzaktan eğitim dönemine ve bu dönemden aldıkları öğretmenlik uygulamalarına ilişkin görüşlerini belirlemeye yönelik sorular yer almaktadır. Geçerlik için oluşturulan taslak, eğitim alanında çalışan iki uzmanın görüşüne sunulmuştur. Gelen eleştirilerden sonra form yapılandırılmıştır.ve dış geçerliği arttırmak için katılımcıların görüşleri çalışmaya doğrudan alınmıştır. Pilot çalışma olarak 15 öğretmen adayına araştırma öncesinde hazırlanmış olan form gönderilmiştir. Hazırlanan yarı yapılandırılmış görüşme formunun işlenirliği sınanmış ve pilot çalışma sonunda sorular üzerinde düzeltmeler ve eklemeler yapılarak forma son hali verilmiştir.

\subsubsection{Veri Toplama ve Verilerin Analizi}

Araştırmada veriler, öğretmen adaylarının yarı yapılandırılmış görüşme formundaki 11 soruya yazılı şekilde cevap vermesi ile elde edilmiştir. Toplanan veriler içerik analiziyle çözümlenmiştir. Veriler çözümlenirken tümevarımsal bir yaklaşım benimseniştir. Veriler, kavramlar ve temalar etrafında birleştirerek anlaşılır hale getirmek için içerik analizi tercih edilmiştir.

Veriler, analiz sonucunda ortaya çıkan tema ve kategoriler ile karşılaştırma yapılabilmesi için sayıya indirgenmiştir. Buna aracı olarak da sistematik ve pratik bir analiz sağlayacak yazılım kullanımı tercih edilmiștir ve kurulan hiyerarşik ilişkiler ile veriler sistematik ve hızlı bir şekilde kodlanmıştır. Analizin yapılması için “MAXQDA 2020" paket programı kullanılmış ve içerik analizi tekniğiyle analiz edilmiştir.

Verilerin analizinde izlenen adınlar şu şekildedir:

- Öğretmen adaylarından elde edilen veriler araştırmacı tarafından dijital ortama aktarılmış ve çözümlenmiştir.

- Görüşme formu ve cevaplar alandan bir uzamana verilmiş, yanlışların veya eksikliklerin kontrol edilmesi yoluna gidilmiştir.

- Elde edilen her soruya ilişkin tema ve alt temaların seçenekleri hazırlanmıştır.

- $\quad$ Bu değerlendirmelerden sonra öretmen adaylar1na sorulan sorular için bir kodlama anahtarı oluşturulmuştur.

- Veriler ve kodlama anahtarını eğitim bilimlerin- den bir uzmana verilmiş ve uzmanlar ile araştırmacı birbirinden bağımsız biçimde her bir soru için işaretletme yapmıştır.

- Buradan hareketle verilerin güvenirlik hesaplamaS1, Miles ve Huberman'ın formülü ile sağlanmıştır: "Uzlaşma Yüzdesi = Görüş Birliği / (Görüş Birliği + Görüş Ayrılığı) x 100".

Araştırmacılardan başka bir uzmanın analiz sürecine dahil olması ve sonuçların karşılaştırılması sonucunda $\% 80$ oranında fikir birliğinin sağlanması kodlamanın güvenirliğini sağlamaktadır (Büyüköztürk vd., 2010). Görüşme sorularının güvenirlik analizi Tablo 2'de verilmiştir.

Tablo 2. Güvenirlik Analizine İlişkin Bulgular

\begin{tabular}{cc}
\hline Soru Numarası & Güvenirlik Yüzdeleri \\
\hline 1 & 85 \\
2 & 87.7 \\
3 & 90.5 \\
4 & 86.3 \\
5 & 91.2 \\
6 & 92.8 \\
7 & 89.7 \\
8 & 87.4 \\
9 & 92.7 \\
10 & 85.3 \\
11 & 91.8 \\
\hline $\mathrm{x}$ & 100 \\
\hline
\end{tabular}

\section{BULGULAR}

Bu bölümde, öğretmen adaylarından toplanan verilerin analizi sonucu elde edilen bulgular sunulmuştur.

Tablolarda verilen katılımcı görüşleri ile kodlardan bahsetme durumları, kodlanmıș ve kodlanmamıș belgeler olarak tabloda yer alan değerlerde farklılık oluşturmaktadır. Bunun sebebi olarak kodun katılımcı say1sı bakımından bahsedilme sıklığı ve ilişkili kategorinin tablo istatistiklerinde kodlanma sıklığının farklılaşmasıdır. Öğretmen adaylarının aynı kategoride birden fazla koddan bahsettikleri değişkenlerde, kodlardan bahseden katılımcı sayısında artış belirirken, her katılımcı raporu, ilgili kategori için sadece bir kez kodlanmıştır.

Tablolarda yer verilen katılımcıların kodlardan bahsetme durumları ile belirttikleri görüşler, kodlanmış 
ve kodlanmamış belgeler olarak tabloda farklılaşmaktadır. Kodun katılımcı sayısı içinde bahsedilme sıklığı ve onunla ilgili kategorinin tablo istatistiklerinde kodlanma sıklığı sonucu bu farklılık ortaya çıkmaktadır. Katılımcılar, aynı kategoride birden fazla koddan bahsettiğinde, kodlardan bahseden katılımcı sayısında artış olur ve her katılımc1, ilişkili kategori için sadece bir kez kodlanmış şekilde görülür. Araştırma kapsamında toplam 11 ana kategori vardır. Bu ana kategorilere ilişkin katılımcı görüşleri doğrultusunda alt kategoriler oluşturulmuştur.

Tablo 3 incelendiğinde, 75 öğretmen adayının uzaktan eğitimin etkili olmadığını düşündüğünü belirttiği görülmektedir. 46 katılımcının, etkili olama durumu$\mathrm{nu}$ dersin uygulanışı ve hocalar ile ilişkilendirdikleri görülürken, 29 katılımcının ise teknik yetersizlikler ile ilişkilendirdiği görülmektedir. Katılımcıların 42'si ise uzaktan eğitim uygulamalarını yeterli bulduklarını belirtmişlerdir.

Öğretmenlik uygulamasının yeterli olmadığını belirten öğretmen adaylarından bazılarının görüşleri şu şekildedir;

k.18: Uzaktan Eğitim uygulamasını ciddi anlamda kötü buldum. Dikkatimi toplamakta fazlasıyla zorlandım. Dersi dinlemek için çoğu zaman kendimi zorladım.

k.38: Uzaklık- yakınlık kavramlarını karşılaştıracak olursam tabiki yakınlığı tercih ederim. Tecrübelerin hayatımızdaki rolü büyüktür. Yaşayarak, görerek daha etkili sonuçlar elde ederiz. Uzaktan eğitimde ise bu uygulamalı tecrübelerin olmaması pratiklik kazanmak açısından uzaktır. Dersin tamamen teknolojiyle yapılmış olması fiziksel olarak bizleri yormakla birlikte psikolojik olarak da dersi sıkıcı bulmamıza sebep oluyor. Olumlu açılardan bakacak olursak zamanı daha rahat kullanmamız açısından iyi. Daha çok makale inceleyerek daha çok bakış açısı kazanabiliyoruz. Genel özetleyecek olursa Uzaktan Eğitim uygulamalarını çok etkili bulmamaktayım. k.40: Eğitimden geri kalmamak için uzaktan eğitim uygulanmasının doğru bir karar olduğunu düşünüyorum ama etkililiğine gelindiğinde çok etkili olmadığını düşünüyorum. Etkili olması için imkanlar genişletilmelidir. İnternet sorunu çözülmelidir. Çünkü evinde interneti olmayan öğrenciler ya da olup da interneti çekmeyen öğrenciler derse bağlanmakta zorluk yaşamaktadır. Kimsenin mağdur olmaması sağlanmalıdır.

k.43: Etkili olduğunu söylemek çok zor. Mesela ilk haftalarda çoğu derse girebilen çoğu kişi giriyordu. Ancak sonra katılımcı sayısı oldukça düştü. Hatta son haftalarda bazı öğretmenlerimizin derslerine katılım 10 kişiyi anca bulmakta. Ayrıca karşıdan sözel bir anlatım var etkinlik yok ki ne kadar duyu işin içine girerse o kadar kalıcılık söz konusu denmekteydi. Böyle bir uygulamanın bu şartlarda ne kadar etkili olduğu söylenebilir ki?

k.47: Çok fazla etkili bulmadım. Çünkü ister istemez yüz yüze olan eğitimle kıyaslama yapıyorum ve onu düşününce fazla etkili olduğunu düşünmüyorum. Ayrıca maddi olanaklara da (internet, bilgisayar...) sahip olma ya da olmama durumu böyle düşünmemi etkiliyor ister istemez.

k.80: Uzaktan eğitim uygulamalarıyla sınıf ortamı teknoloji sayesinde internet üzerinden oluşturulmaya çalışıldı. Ancak gerçek bir sınıf ortamında ders işlenmediği için yeterince etkili olmadığını düşünüyorum. Sınıfta uyguladığımız birçok yöntem ve teknik uzaktan eğitim ortamında kullanılamıyor. Daha çok verilen ödevler üzerinden ilerliyoruz.

k.95: verimi açısından çok faydalı bulduğumu söyleyemeyeceğim. Yüz yüze olmadığı için sunum yaptığımız zaman internetten veya herhangi bir kaynaktan edinilen bilgileri sunuyoruz. Ama bu da ilgi çekici şekilde dinlenme sağlamıyor. Öğrenciler ve öğretmenler sadece prosedürden uygulamalara katılıyor.

k.98: Uzaktan eğitim uygulamalarını çok etkili bulamasam da bu süreçte en azından bizi eğitim ve öğretimin bir şekilde devam edeceğine ikna etti. Elbette sınıf orta-

Tablo 3. UE Uygulamalarının Etkili Olma Durumu Temasına İlişkin Alt

Temaların Yüzde ve Frekans Dağılımları

\begin{tabular}{lcc}
\hline UE Uygulamalarının Etkili Olma Durumu & f & Yüzde \\
\hline Etkili değildir & 75 & 68.81 \\
$\quad \square \quad$ Dersin Uygulanışı ve Ders Hocasından Kaynaklı & 46 & 42.20 \\
$\quad$ Yetersizlikler & & \\
$\square \quad$ Teknik Yetersizlikler & 29 & 26.61 \\
Etkilidir & 42 & 38.53 \\
\hline Toplam & 109 & 100
\end{tabular}


mında yüz yüze eğitim kadar alınan geri bildirim anında ve daha etkili olmuyor. Bazı teknik sıkıntılar süreci uzatiyor.

k.99: Çok az etkili buldum. Kendimden örnek verilirse; bizim burada internet çok az çekiyor bu yüzden derslere girmek için merkeze gitmek zorunda kaldım. Böyle uzaktan eğitim sistemi yapılacaksak derse girecek öğrenciler için farklı çözüm yolları düşünülmesi gerekirdi.

Katılımcı görüşlerinden yola çıkarak, öğretmen adaylarının uzaktan eğitimi verimsiz olarak değerlendirdikleri görülmektedir. İnternet bağlantısı problemleri ve donanımsal eksiklikler gibi olumsuzluklardan bu sürecin etkili ilerlemediğinin belirtmişlerdir.

Araştırmanın bir sonraki bulgusunda öğretmen adaylarının yüz yüze eğitimin ve uzaktan eğitimin karşılaştırmasına yönelik belirttikleri görüşler verilmiştir.

Tablo4'e göre, araştırmaya 95 katılımcının yüz yüze eğitimi daha etkili bulduğu belirlenmektedir. Katılımcllardan 12'si ise her iki eğitimi de etkili bulmuştur. Uzaktan eğitimi etkili bulan 3 öğretmen adayı olduğu yine Tablo 4'te görülmektedir.

Yüz yüze eğitimi daha etkili bulan öğretmen adaylar1nın görüşlerinden bazıları şu şekildedir;

k.1: Yüz yüze eğitimde gördüğümüzü canlı olarak uygulama vardı. Fakat uzaktan eğitimde asosyallik var. Herkes eşit imkanlara sahip değil.

k.38: Gerek öğrenmenin gerçekleşmesinde gerekse iletişim kurmada yüz yüze olmanın etkisi büyüktür. Yüz yüzeyken göz teması kurularak yapılan konuşmaları, davranışları her zaman çok yapıcı bulmaktayım. Yüz yüze eğitimde uygulama çalışmaları ne kadar fazlaysa uzaktan eğitimde bir o kadar azdır. Tabi bu azlık yeterlilik açısından sorun teşkil etmektedir. Örnek vermek gerekirse daha önce voleybol oynamamış bir çocuğu düşünelim. Bu çocuk pencerenin arkasından dışarıda voleybol oynayan akranlarını uzaktan izlemektedir.
Belli bir süre sonra kendi kendine voleybol oynamanın kolay olduğunu ve çok iyi oynayabileceğini düşünmeye başlar. Ne zaman dışarı çıkar ve topu eline almaya başlar işte o zaman topu atmakta zorlanır. Aslında hiç de o kadar kolay olmadığının farkına varır. İşte uzaktan eğitim de böyledir. Yüz yüze eğitimin verdiği pratikliği kazandıramaz.

k.47: Yüz yüze eğitim uzaktan eğitime göre çok daha iyi. Her anlamda hem de. Öğrenciyle iletişim kurma olsun, dersteki karşılıklı öğrenci-öğretmen ilişkisi olsun, yüz yüze eğitimdeki gerek özveri gerek disiplin gerekse dersin gerektirdiği saygı ve sevgi ortamı olsun uzaktan eğitimle kıyaslanamaz bile. Uzaktan eğitimde gerçek bir sınıf ortamı yok en başta. Öğretmen-öğrenci ilişkisi yok denecek kadar az. İletişim kopuk. Maddi olanakların herkesin birbiriyle aynı olmaması da apayrı bir durum. Bu da eğitimde eşitlik altındaki eşitsizliği oldukça ortaya çıkarıyor.

k.53: Yüz yüze eğitim tabi ki uzaktan eğitimden çok çok iyi. Uzaktan eğitimde etkileşim daha zor hepimiz aynı anda derse katılamıyoruz. $\mathrm{O}$ an mikrofonumuz açılmıyor ya da internet gidiyor ve dersin o kısmı kaçmış oluyor. Hepimiz konuşalım desek seslerimiz birbirimize karışıyor. Dersin hazırlık süreci de bir o kadar sıkıntılı oluyor sunum yapacağımız zaman teknik arızalar çıkabiliyor. Ama yüz yüze eğitimde sınıf koşullarını önceden bildiğimiz için hazırlık yapmamız daha kolay oluyordu

k.62: Uzaktan eğitimi yüz yüze eğitimle karşılaştırd1ğımızda öğretmen ile öğrenci birbirinden ayrı kalıyor. Yüze yüze eğitimde sabah 9'deki derse 1 saat öncesinden kalkıp hazırlanıp gidip oturarak ders dinliyorsun, ama uzaktan eğitimde o derse yataktan bile çıkmadan ders diliyorsun. Yüz yüze eğitimde dersi full dinliyorsun ama uzaktan eğitimde ise başta dinleyip bırakıyorsun

k.71: Yüz yüze eğitimde duygularımızı kullanabiliyoruz. Hocaya sormak istediğimiz soruyu anında sorabiliyoruz. O eğitim ortamına gelen herkes o an yaşanan-

Tablo 4. Karşılaştırma Temasına İlişkin Alt Temaların Yüzde ve Frekans Dağılımları

\begin{tabular}{lll}
\hline Karşılaştırma & $\mathbf{f}$ & Yüzde \\
\hline Yüz Yüze Eğitim Daha İyidir & 95 & 87.16 \\
İkisi De İyidir & 12 & 11.01 \\
Uzaktan Eğitim Daha İyidir & 3 & 2.75 \\
\hline Toplam & 109 & 100
\end{tabular}


larla uyarılıyor sadece öğrencilik görevimiz var. Fakat uzaktan eğitim öyle değil mekanik ve soğuk hocaya soru sorarken internet kesilebiliyor, görüntü donuyor, mikrofonumuz çalışmıyor ya da sistem yoğunluktan dışarıya atıyor. Evde evin kızı görevlerini yerine getirmen gerekiyor. O kadar boş vaktimiz olamayabiliyor. Sorumluluklarımız Çanakkale'dekinden fazla oluyor.

Katılımcıların yüz yüze eğitimi daha verimli bulduklar1 ve eğitim öğretimin uzaktan eğitimde etkili olmadığg belirttikleri görüşlerden tespit edilmektedir.

Araştırmanın bir sonraki bulgusunda öğretmen adaylarının uzaktan eğitimin olumlu yanlarına ilişkin belirttikleri görüşler verilmiştir.

Tablo 5 incelendiğinde, 39 katılımcının uzaktan eğitimin olumlu yanı olarak zaman tasarrufu alt kodundan bahsettiği görülmektedir. Öğretmen adaylarından 34 'ünün ise eğitimde sürekliliğin sağlanmasının bu uygulamaların olumlu yanı olduğunu belirttikleri görülmektedir. Katılımcıların 32'si evde olma boyutunu öğretmenlik uygulamasının olumlu yönü olarak değerlendirmişlerdir.

Evde olma boyutunu olumlu bulan öğretmen adaylarının görüşlerinden bazıları şu şekildedir;

k.13: Son sınıf öğrencisi olduğum için benim adıma en olumlu yanı evde daha çok ders çalışabilmem oldu di- yebilirim. Kpss sürecini evdeyken daha kaliteli yürütebiliyorum.

k.27: Uzaktan eğitim ev konforunda derslere ulaşımı sağlarken hazırlık, araç ulaşımı gibi yorucu süreçlerden alıkoymaktadır

k.45: Tek olumlu yanı evde koltuk üzerinde daha rahat ders dinlemek olabilir. Başka hiçbir olumlu yanını görmüyorum.

k.47: Sadece evdeki rahatlık ortamından yararlanma olabilir. Bunun dışında olumlu bir yanını görmüyorum.

k.88: Uzaktan eğitim en güzel tarafı zaman tasarrufu sağlaması ve öğrencinin evinden çıkmadan dersleri takip etmesini sağlamaktadır.

Öğretmen adaylarının görüşlerine göre, uzaktan eğitimde zamandan tasarruf etmenin olumlu bir yan olduğunu belirttikleri ancak yine de çok fazla olumu bir yan bulamadıklarını ifade ettikleri görülmektedir.

Araştırmanın bir sonraki bulgusunda öğretmen adaylarının uzaktan eğitimin olumsuz yanlarına ilişkin belirttikleri görüşler verilmiştir.

Tablo 6'da öğretmen adayların uzaktan eğitimin olumsuz yönlerine ilişkin görüşleri incelendiğinde, 68 öğretmenin eğitimde fırsat eşitliğinin olmadığı alt temasına

Tablo 5. Uzaktan Eğitimin Olumlu Yanları Temasına İlişkin Alt Temaların Yüzde ve Frekans Dağılımları

\begin{tabular}{lcc}
\hline Uzaktan eğitimin olumlu yanları & f & Yüzde \\
\hline Zaman Tasarrufu & 39 & 35.78 \\
Eğitimin Sürekliliğin Sağlanması & 34 & 31.19 \\
Evde Olmak & 32 & 29.36 \\
Derse Ulaşabilirlik & 28 & 25.69 \\
Online Eğitim Sürecini Öğrenme & 7 & 6.42 \\
Sınav ve Ödevlerin Daha Kolay Yapılması & 5 & 4.59 \\
Olumlu Bir Yanı Yok & 5 & 4.59 \\
Devam Zorunluluğunun Olmaması & 3 & 2.75 \\
\hline Toplam & 109 & 100 \\
\hline
\end{tabular}

Tablo 6. Uzaktan Eğitimin Olumsuz Yanları Temasına İlişkin Alt Temaların Yüzde ve Frekans Dağılımları

\begin{tabular}{lcc}
\hline Uzaktan Eğitimin Olumsuz Yanları & f & Yüzde \\
\hline Fırsat Eşitliği Yoktur & 68 & 62.39 \\
$\square \quad$ İnternet ve Bağlantı Sorunları & 58 & 53.21 \\
$\square \quad$ Teknolojik Araçların Eksikliği & 15 & 13.76 \\
İletişimsizlik & 42 & 38.53 \\
\hline Derslerin İşleniş Şekli & 40 & 36.70 \\
Sinıf ve Okul Ortamından Uzaklık & 29 & 26.61 \\
Öğrencilere Sunduğu Özgürlük & 16 & 14.68 \\
Ödevlerin Yoğunluğu & 6 & 5.50 \\
\hline Toplam & 109 & 100 \\
\hline
\end{tabular}


yönelik görüş belirttiği görülmektedir. Fırsat eşitli olmadığını düşünen 68 öğretmenden 58'i bunu internet ve bağlantı sorunlarıyla, 15'i ise derse girmeyi sağlayacak teknolojik araç ve gereçlerin yetersizliği ile ilişkilendirdiği görülmektedir. Uzaktan eğitimin olumsuz yanlarını derslerin işleniş şekli ile ilişkilendiren 40, sınıf ve okul ortamından uzaklık ile ilişkilendiren ise 29 öğretmen adayının olduğu tespit edilmektedir.

Katılımcılardan, uzaktan eğitimin olumsuz yanlarını sınıf ve okul ortamindan uzaklık ile ilişkilendirenlerden bazılarının görüşleri şu şekildedir;

k.10: Kesinlikle öğretmen-öğrenci ilişkisi olumsuz etkilenir. Sınıf ortamında oluşan diyalog uzaktan eğitim yoluyla oluşmayabilir. Bunda birçok etken mevcuttur. Örnek olarak öğrencinin derse kendini verememesi, iletişim kuracağ teryallerin eksikliği verilebilir.

k.31: Soğuk bir ortam. Elbette hocalarımız bizim moralimizi yüksek tutmak için ellerinden geleni yapıyorlar. Yardımcı oluyorlar. Ancak yine de içimizdeki bu üzüntü geçmiyor. Özellikle son sınıf öğrencisi olduğum için sanırım daha fazla üzüntü duyuyorum. Yüz yüze eğitimdeyken ders saatinden en az 1 saat önce uyanmış oluyordum. Bu süreçte hazırlık, kahvaltı derken derse girdiğimde zihnim açılmış rahatlamış oluyordum. Ama şimdi telefon alarmımı ders saatinden 10 dakika önceye kurup kahvaltı bile yapmadan ders dinlemeye çalışıyorum. Her ne kadar bu sefer yataktan çıkıp kendimi derse hazırlamam gerekiyor desem de ders günü geldiğinde yine yapamıyorum. Uzaktan eğitimin benim derslere olan ilgimi düşürdüğünü düşünüyorum.

k.69: Yüz yüze iletişim, sınıf ortamı, derslere katılım, soru cevap uygulamaları, anlamadı̆̆ın/takıldığın yerlerde söz almak, disiplin gibi birçok açıdan eksiklikler var.

k.86: Öğretmenin bizi görmüyor olması, bir sınıf ortamı bulunmaması, psikolojik olarak derse uyum sağlamak- ta zorlanıyor olmak gibi olumsuz yanları var.

k.98: Sınıf ortamı gibi birbirimizle yaparak yaşayarak öğrenmelerle işlediğimiz dersler gibi değil daha çok anlatım tarzına yönelik şekilde dersleri işlememiz biraz sıkıcı bir hal aldı.

k.99: Sınıf ortamında olduğu gibi bir fikir alışverişi yapamamak, öğretmenle birebir göz kontağı kuramamak uzaktan eğitimin olumsuz yanları olduğunu düşünüyorum. Tabi sadece eğitsel kısmı ile değerlendirmemek gerekiyor, okul sadece eğitim alınan bir ortam değildir. Sınıf ortamının, toplulukla birlikte olmanın, arkadaşların ile paylaşım içinde olmanın, öğretmenlerle ders harici sohbet edebilmenin kıymetini hatırlatıyor uzaktan eğitim maalesef en çok eğitimin sosyal yönünü zedeliyor..

k.108: Sınıf ortamını hissedememek. Biz her gün sınıfa geldiğimizde "Evet birazdan hocamız gelecek ve biz bir sürü yeni bilgiyle dolacağız" mantığıyla geliyoruz ancak şimdi yataktan kalkmamıza bile bazen gerek kalmıyor. Bu da öğrenmeye başlaman gereken zamanın geldiğini sana hissettiremiyor dolayısıyla dikkatini toplayabilmek zorlaşıyor

Katılımc1 görüşleri doğrultusunda, uzaktan eğitimde öğretmen adaylarının, bu süreçte fırsat eşitliği olmay1şının olumsuzluk yarattığını belirttikleri görülmektedir. İletişimsizlik de benzer şekilde bu dönemin olumsuz bir yanı olmuştur.

Araştırmanın bir sonraki bulgusunda öğretmen adaylarının uzaktan eğitimin eksikliklerine ilişkin belirttikleri görüşler verilmiştir.

Tablo 7'ye göre, öğretmen adaylarının uzaktan eğitimdeki eksikliklere yönelik görüşleri incelendiğinde, 66 katılımcının internet ve bağlantı sorunlarına yönelik görüş bildirdikleri tespit edilmektedir. Katılımcılardan 17'si uygulamanın eksikliği, 10'u öğretim elemanlarından kaynaklanan eksiklikler kategorisine yönelik görüş

Tablo 7. Uzaktan Eğitimdeki Eksiklikler Temasına İlişkin Alt Temaların Yüzde ve Frekans Dağılımları

\begin{tabular}{lcc}
\hline Uzaktan Eğitimdeki Eksiklikler & f & Yüzde \\
\hline İnternet/Bağlantıdan Kaynaklanan Sorunlar & 66 & 60.55 \\
Uygulama Eksikliği & 17 & 15.60 \\
Diğer & 15 & 13.76 \\
Eksiklik Yoktur & 14 & 12.84 \\
Öğretim Elemanlarından Kaynaklı Eksiklikler & 10 & 9.17 \\
Sürece Hazırlıksız Girmek & 5 & 4.59 \\
Motivasyon Eksikliği & 4 & 3.67 \\
\hline Toplam & 109 & 100
\end{tabular}


belirtmişlerdir. 14 öğretmen adayı ise bu süreçte bir eksiklik olmadığını düşünmektedir.

Uzaktan eğitimdeki eksiklikler temasında internet/ bağlantı sorunları kategorisinden bahseden öğretmen adaylarının görüşlerinden bazıları şu şekildedir:

k.43: gerekli donanım eksikliği diyebilirim. örnek vermek gerekirse benim bilgisayarım olmamış olsaydı ben telefondan giremezdim çünkü telefonum uygulamayı kaldıramayacak kadar eski. bir diğer nokta ise sırf bu ue için bulunduğum eve wi-fi almak zorunda kaldım. ama alamayan arkadaşların olduğunu da biliyorum. örneğin bir arkadaşım kars'a ailesinin yanına döndü ve telefon zar zor çekiyorken istenen imkanları bulundurmasına imkan yok.

k.44: uygulamanın internet kullanımı fazla olduğundan maddi açıdan öğrencilere zorluk yaratabiliyor.

k.50: teknoloji konusunda yetersiz bilgiye sahiptim. bu aşamada zorluklar çektim. internet erişimini sağlayamadığımız zamanlar derse katılamıyoruz.

k.61: internet bağlantısından ya da uygulamadan kaynaklanan teknik sıkıntılar olmaktadır. aynı zamanda her öğrenci teknolojiyi etkili bir şekilde kullanamamaktadir.

k.70: anında dönüt bekleniyor ama kopukluk olunca bizler de sorulanlara cevap veremiyoruz. kimi zaman ifade etme güçlüğü yaşıyoruz.

k.88: uzaktan eğitim uygulaması için çok fazla internet gerekmektedir. internetim yetmediği için iki hafta dersleri takip edemedim. Birçok kişinin benimle aynı sorunu yaşadığını düşünüyorum. böyle bir uygulama yapılıyorsa öğrenciye internet konusunda yardım edilmesi gerektiğini düşünüyorum.

k.92: uzaktan eğitimin değil ama kullanılan internetten dolayı ses ve görüntünün sağlık bir şekilde iletilmemesi bir eksiklik olarak değerlendirilmiştir.

k.105: internetten dolayı kaynaklanan sorunlar dışında herhangi bir eksiklik görmüyorum. k.97: internet problemine bağlı olarak kullandığımız uygulamanın sürekli donması ve ders anlamında kopukluklar yaşanması.

Uzaktan eğitimdeki eksiklikler temasında diğer kategorisinden bahseden öğretmen adaylarının görüşlerinden bazıları şu şekildedir:

k.2: Disiplin konusunda eksiklikler.

k.16: Her ne kadar devam zorunluluğumuz olmadığ söylense de yine de yoklama alınması

k.38: canlı dersler yapılırken ev durumunun müsait olmaması (ses, gürültü, kalabalık, küçük çocuklar gibi) canlı derslere katılmamızı engelliyor. Bu durumda da derslerden kendimi uzak hissedebiliyorum

k.57: Sadece öğretmenin görüntüsünü görebiliyoruz. Aslında tüm sınıfın görüntülü konuştuğu bir ortam olsa daha faydalı olabilir. Tabi bu mümkün değil.

k.84: Ödevler son dakika söyleniyor. Sadece yapılmak için yapıllyor.

Öğretmen adaylarının uzaktan eğitimde internete erişimi olmayan arkadaşlarının ya da kendilerinin büyük sorunlar yaşadıklarını dile getirdikleri görülmektedir. İnternet erişimini sağlayıp ders anındaki kopmalardan kaynaklanan anlık sorunlarda büyük eksiklik olarak görülmektedir.

Araştırmanın bir sonraki bulgusunda öğretmen adaylarının uzaktan eğitimde öğretim elemanlarına ilişkin belirttikleri görüşler verilmiştir.

Tablo 8 incelendiğinde, araştırmaya katılım gösteren 92 öğretmen adayı öğretim elemanlarını bu süreçte yeterli bulduğu, 20 katılımcının ise yeterli bulmadığı görülmektedir.

Uzaktan eğitimde öğretim elemanlarını yeterli bulduğunu belirten öğretmen adaylarından bazılarının görüşlerine aşağıda yer verilmiştir.

k.3: Açıkçası öğretim elemanlarını bu süreçte verdikle-

Tablo 8. Uzaktan Eğitimde Öğretim Elemanları Temasına İlişkin Alt Temaların

Yüzde ve Frekans Dağılımları

\begin{tabular}{lcc}
\hline Uzaktan Eğitimde Öğretim Elemanları & f & Yüzde \\
\hline Yeterli & 92 & 84.40 \\
Yeterli Değil & 20 & 18.35 \\
\hline Toplam & 109 & 100 \\
\hline
\end{tabular}


ri eğitimden dolayı teşekkür ederim. Fazlasıyla bizimle ilgileniyorlar ve sorunlarımızı çözmeye çalışıyorlar.

k.13: Teknolojiye hakim olan öğretmenlerimiz duruma hemen yeni çözümler getirerek toparlandı fakat bazı öğretmenlerimiz hem teknolojiyi kullanma bakımından yetersiz kaldı hem de dersleri uygulamaya dönük olduğu için açıkçası ilk haftalar ne yapacağını bilemez hale geldi. Onlara da hak veriyorum çünkü örneğin müzik eğitimi dersini online biçimde ne kadar kaliteli verebilirlerse o kadar vermeye çalışıyorlar. Bu yüzden de şanslı olduğumu düşünüyorum çünkü öğretmenlerimiz pes etmeyi sevmiyor.

k.27: Uzaktan eğitim derslerinde öğretim elemanları öğrencilerden daha bilinçli ve yeterince anlayışlı hareket etmektedir. Bu sürece onlar da öğrenciler kadar hazırlıksız yakalanmış olmalarına rağmen adapte olmakta öğrenciler kadar zorlanmamışlardır.

k.32: Evet bence gayet başarılı şekilde süreci yönetebiliyorlar ve eksik kalabileceğimiz kısımlar için daha çok çaba sarf ediyorlar.

k.38: Dersleri ve verilen ödevlere baktığımda öğretim elemanlarının görevlerini titizlikle yaptığını düşünüyorum. Yüz yüze eğitimin verdiği faydaların uzaktan eğitimde de verilmesi için ellerinden geleni yapıyorlar. Bu açıdan öğretim elemanlarını gayet yeterli bulmaktayım.

k.40: Uzaktan eğitimle ders anlatmak kolay bir şey değildir. Bu şartlar altında yeterli buluyorum çünkü öğretim elamanları ellerinden geldiği kadarıyla yardımcı oluyor. Konuları sunum şeklinde açıp bizim görerek takip etmemize imkân taniyorlar. Sunumlardan yararlanmamız için übys 'ye yüklüyorlar.

k.53: Bence yeterli öğretmenlerimiz. Hatta gün geçtikçe sistemi daha çok kullandıkça öğretmenlerimiz yeni şeylerle karşıllyorlar bizi. Ve onlardan yeni şeyler öğreniyoruz. Sonuçta onlarda biz de bu sistemi ilk defa kullanıyoruz. Özellikle bizim sunum yapacağımız zaman öğretmenlerimiz bir aksaklıkta hemen çözüm yolu üretmeye çalışıyorlar. Bize yardımcı oluyorlar

k.76: Yeteri kadar idare edebiliyorlar zaten teknoloji çağında olduğumuzu düşünürsek herkes kendi dersini idare ettirecek kadar bilgiye sahip olduğunu düşünüyorum.

k.82: Tüm öğretim elemanlarını yeterli buluyorum. Ders içerikleri zaten yüz yüze eğitim gibi devam edi- yor, ödevler duruma uygun uyarland. Normal durumdan tek farkı teknolojiye uyum sağlayıp dersleri eksiksiz gerçekleştirmek ve tüm öğretim elemanları bu konuda yeterli.

Yeterli değildir kategorisine ilişkin görüş bildiren katılımcılardan bazılarını görüşleri ise aşağıda verilmiştir.

k.8: Uzaktan eğitim için özel bir çaba gösterdiklerini düşünmüyorum. Çünkü çoğu öğretmen dersi yüz yüze nasıl işliyorlarsa o şekilde devam ediyor. Daha sohbet havasında ders işlendiğinde katılımın ve akılda kalıc1lığının artacağını düşünüyorum. Ders anlatma konusunda yeterli olunduğunu düşünüyorum. Sadece derse adapte olmak için daha çok soru cevap sistemi uygulanması gerektiğini düşünüyorum.

k.17: Yeterli bulmuyorum. Uygulama içerisindeki mikrofon giriş desteği ayarlarına kadar öğrencilere soruluyor.

k.18: Bazı öğretim elemanlarının dersi eksiksiz yapmak adına öğrencilerin yaşayabileceği sorunları göz ardı ettiğini düşünüyorum. İmkânların olup olmadığını sorgulamadan herkesten aynı zamanda aynı katılımı performansı ya da katılımı beklediklerini düşünüyorum.

k.43: Çoğu değil. Yüz yüze eğitimde dahi verim alamadığımızı düşündüğümüz öğretim elemanlarının UE'de kaliteyi yakalamaları imkansız bence.

k.71: bazıları da bu konuda pek yardımcı olmuyor. Eğitim zorunlu değil evet bu bir sorumluluk ama buna zorlamamaları gerekiyor. Her an ulaşım sağlayamayabiliriz dersleri sonradan da izleme imkanımız var bu güzel bir çalışma derslerini kaydetmeyerek o an erişim sağlamayan öğrencileri mağdur etmemeleri gerekiyor.

k.81: Öğretim elamanlarının çoğu teknolojiyi kullanamamakta ve uzaktan eğitim sistemine ayak uyduramamakta, bu yüzden öğretim elemanlarının çoğu dersleri salt bir şekilde anlatıp geçmektedir. Ders anlatımın yanında öğretim elemanları kullanılan programda bulunan tahtayı veya alternatif başka şeyleri kullanmayı bilse ve uygulasa uzaktan eğitim bir nebze daha verimli olabilir

k.84: Hepimizin çok hazırlıksız olduğunu düşünüyorum. Yapılan sunumlar anlatılan dersler havada kal1yor. Öğretmenlerimiz dersi sadece geçmemize odaklandığ1 için neredeyse hepsi derslerde bizim sunum yapmamızı istiyor. Bu yüzden öğretmenler bu noktada pasif kalıyor. 
k.99: Öğretim elemanlarını yeterli bulmuyorum, dersler işlenmek için işleniyor öğenciden herhangi bir dönüt alınmıyor. Öğretmen sunumu yansıtıp okuyor bu şekilde bir derse ihtiyacımız olduğunu düşünmüyorum bize pdf olarak atıldığında da aynı sonucu elde edeceğimizi düşünüyorum

Katılımcılar, öğretim elemanlarının bu süreçte "ellerinden geleni yaptıkları"nı belirtmiş ve çoğunluk olarak bu süreci iyi idare ederek yeterli olduklarını ifade etmişlerdir.

Araştırmanın bir sonraki bulgusunda öğretmen adaylarının uzaktan eğitimde öğretmenlik uygulamasına ilişkin belirttikleri görüşler verilmiştir.

Tablo 9'da öğretmen adayların uzaktan eğitimde öğretmenlik uygulamasına ilişkin görüşleri incelendiğinde, 55 katılımcının tecrübe açısından eksikliktir kategorisine yönelik görüş belirttiği görülmektedir. Katılımc1lardan 48'i uygulamanın yerini tutmayacağını, 37'sinin verimsiz olacağını belirttiği, 9 katılımcının ise telafi edilmesi gerektiğin düşündüğü tespit edilmektedir.

Tecrübe açısından eksiklik olduğunu düşünen öğretmen adaylarının görüşlerinden bazıları şu şekildedir;

k.18: Uygulamalı staj dersi mesleğe adım atmadan pratikte mesleği görme ve yaşama fırsatı sunuyordu. Şimdi bu durumda diğer derslerden bir farkı kalmadı. Dolayısıyla tecrübe olması açısından eksikliğini hissedeceğiz.

k.33: işte uzaktan eğitimin en büyük sıkıntısı biz öğretmen adayları için bu konu. Çünkü bizler okul ortamında çocuklarla etkileşim içinde olmalıyız ki öğretmen olduğumuzda sınıf hâkimiyeti sağlayabilelim ve sonuçta yüz yüze olduğunda her an her şeye hazır oluyor insan ve bu da öğretmenlik deneyimi kazandırıyor. Uzaktan eğitimde bu yok maalesef. Çocuklarla sınıfta yapmamiz gereken etkinlikleri ev de anamız babamız ya da dedemizle yapmak sonuçta ne kadar etkili olabilir ki??? k.43: Yetersiz. Bizim elimizden tecrübe edinme fırsat1mızı aldılar. Bir yemeğin tarifini bilebilirsiniz ama en iyisi mutfağa gidip o yemeği pişirmektir. Öğretmenlik uygulamaları da bizim için böyleydi. Tarifi biliyoruz ama mutfağa giremiyoruz dolayısıyla yemek pişmiyor..

k.65: Uygulama tecrübe anlamında bize daha fazla şey katabiliyordu. Teorik olarak ders işlenilmesi yüzeysel kalabiliyor. Önceki dönemlerde ve bu dönemin ilk haftalarında edindiğimiz tecrübeler bize teorik derslerde de yardımc1 oluyor.

k.86: Deneyim açısından staj yapmak gerekliydi. Öğrencilerle vakit geçirmek, ders planları hazırlamak öğretmenliğe alıştırıyordu bizi. Fakat yaşadığımız günlerde stajımızın yapılamaması ve yapılabileceği günlerin belirsiz olması nedeniyle stres seviyemiz artıyordu. Mezuniyetimizle ilgili belirsizlik ortadan kalkmış oldu. Bu yüzden bu kararı destekliyorum.

k.100: Teorik uygulamalar, yaparak ve yaşayarak yapılan uygulamaların yerini tutmuyor. Okul atmosferinde ve öğrencilerle bir aradayken, canlı öğretim ortamlarında daha fazla tecrübe kazanıyorduk. İçinde bulunduğumuz durumdan dolayı bu mümkün olmadığı için böyle devam etmesi elbette ki hiç kimsenin elinde olmayan bir durum. Başka çare olmadığı için en azından böyle devam etmesi hiç yoktan iyidir bana göre.

k.104: İşin teorik kısmı için olumlu olduğunu düşünüyorum fakat uygulama kısminda tabi ki tecrübe eksikliği yaşanacaktır.

k.106: Kesinlikle çok verimsiz olduğunu düşünüyorum. Öğretmenlik uygulaması bence en temel derslerden birisi ve kesinlikle ödev şeklinde değil yüz yüze yapılması gerekiyor. Çünkü çok şey öğreniyorduk. Okuldaki öğretmenler eksiklerimizi söylüyordu. Bir öğrenciye nasıl yaklaşmalıyız omu öğreniyorduk. Aynı zamanda grup arkadaşlarımızla da eksik yönlerimizi söylüyorduk. Sadece teorik olunca yine uygulama öğ-

Tablo 9. Uzaktan Eğitimde Öğretmenlik Uygulaması Temasına İlişkin Alt Temaların Yüzde ve

Frekans Dağılımları

\begin{tabular}{lcc}
\hline Uzaktan Eğitimde Öğretmenlik Uygulaması & f & Yüzde \\
\hline Tecrübe Açısından Eksiklik & 55 & 50.46 \\
Uygulamanın Yerini Tutmaz/Yüz Yüze Olmalı & 48 & 44.04 \\
Verimsiz/Etkisiz & 37 & 33.94 \\
Telafi Edilmeli & 9 & 8.26 \\
Mecburi & 8 & 7.34 \\
Değişiklik Yok & 6 & 5.50 \\
\hline Toplam & 109 & 100 \\
\hline
\end{tabular}


retmenlerimiz bir şeyler söylüyorlar fakat uygulamadaki kadar verimli olduğunu düşünmüyorum. Uygulamada tamamen tüm sorumluluk bize aitti. Kendimizi daha çok öğretmen gibi hissediyorduk ve yaparak yaşayarak öğreniyorduk.

k.108: Çok yanlış bir uygulama olduğunu düşünüyorum. Biz gerçekten şu an bir sınıfa girip ders anlatabilme, sınıfta hakimiyeti sağlayabilme kıvamına yeterince erişemedik. Staja başladığımız yeni sınıflarda bunu daha çok hissediyorduk çünkü geçen dönem staj yaptığımız sınıflarda artık sonlara doğru yavaş yavaş sınıf yönetiminde bir şeyleri kavramaya başladığımızı düşünmeye başlamıştık. Yeni sınıfımızda belki daha önce yaptığımız hataları yapmadan kendimizi deneme fırsatımız olacaktı ancak bu şansımız elimizden kaçtı.

Belirtilen görüşler doğrultusunda, öğretmen adaylarının bir sınıf ortamında olmadan, öğrenciler ile iletişim kurmadan deneyimsiz kalacaklarını, meslek hayatında tecrübe eksikliği yaşayacaklarını ifade ettikleri görülmektedir.

Araştırmanın bir sonraki bulgusunda öğretmen adaylarının öğretmenlik uygulamasında geliştiren boyuta yönelik belirttikleri görüşler verilmiştir.

Tablo 10'a göre öğretmen adaylarının öğretmenlik uygulamasının geliştiren boyut temasına yönelik belirttikleri görüşler incelendiğinde, en çok yüzdeye sahip kategorinin (\%97.25) uygulama boyutu olduğu tespit edilmektedir. Öğretmenlik uygulamasında geliştiren boyutun uygulama olduğunu düşünen 106 katılımc1dan; 61'i bunu tecrübe, 35 katılımcı öğrencilerle aynı ortamda olma, 31'i geri bildirim ve gelişim, 11'i ise kalıcılık alt kodu ile ilișkilendirmiștir. Katılımcılardan 4'ünün ise teorik boyutun öğretmenlik uygulamasında geliştirici boyut olduğunu düşündüğü Tablo 10'da görülmektedir.

Uygulama kategorisinden bahsederek bunu öğrenciler ile aynı ortamda olabilmeyle ilişkilendiren 35 öğretmen adayından bazılarının görüşleri şu şekildedir;

k.10: Kesinlike uygulama boyutunun geliştirdiğini düşünüyorum. Çünkü çocuklarla girilen iletişim, nasıl davranılması ve hareket edilmesine katkı sağlıyor. K1sacası bizim o konuda tecrübe sahibi olmamıza katkıda bulunuyor.

k.13: Tabi ki de uygulama boyutu çünkü bire bir çocukla etkileşim içindeyken teoride öğrendiğimizden çok daha fazlası ile karşılaşıyoruz. Çaresiz kaldığımız durumlarda ne yapmamız gerektiğini öğreniyoruz. Birden fazla karakterde çocuk tanıyoruz, aile durumlarına şahit oluyoruz, kimi zaman kriz durumları ile karşılaşıyoruz ve tecrübe kazanıyoruz. Mesleğimiz gereği de bana göre teorik bilgileri pratiğe aktarmak yani tecrübe kazanmak bizi iyi öğretmenler haline getirecek şeyler. Bu yüzden uygulama boyutunun daha çok değiştirdiğini düşünüyorum.

k.43: Tabiki uygulama boyutu daha geliştiriciydi. Birçok öğrenciyi gözlemleyebiliyorduk. Öğrenciyi gözlemlerken onun kişiliğinden, öğrenme stilinden, ailesine kadar çıkarımlarda bulunabiliyorduk. Hangi ders nasıl anlatılmalı, ne derece kalıcı öğrenmeler sağlayabiliriz bunları kendimiz deneyimliyorduk.

k.66: Uygulama boyutunda daha çok geliştirdiğini düşünüyorum tabi ki. Öğrenciler ile aynı ortamda bulunmak sınıf ortamını görmek ileride karşılaşabileceğimiz zorluklar ve sorunlar ile önceden yüzleşmek ve çözümlerini öğrenmek bize katkı sağlıyor.

k.80: öğretmenlik dersinin teorik olarak bize çok şey katacağını düşünmüyorum. Kesinlikle uygulama yapılamaması bizim deneyim kazanamıyor olmamız açısından eksikliktir. Öğrencilerle yüz yüze sınıf ortamında ders işleyerek kazanacaklarımızın yerini hiçbir şey tutamaz

k.86: Uygulama boyutunun geliştirdiğini düşünü-

Tablo 10. Öğretmenlik Uygulamasında Geliştiren Boyut Temasına İlişkin Alt Temaların Yüzde ve Frekans Dağılımları

\begin{tabular}{ccc}
\hline Öğretmenli Uygulamasında Geliştiren Boyut & f & Yüzde \\
\hline Uygulama Boyutu & 106 & 97.25 \\
$\square \quad$ Tecrübe & 61 & 55.96 \\
$\square$ Öğrencilerle Aynı Ortamda Olabilme & 35 & 32.11 \\
$\square$ Geri Bildirim ve Gelişim & 31 & 28.44 \\
$\square$ Kalıcılık & 11 & 10.09 \\
Teorik Boyutu & 4 & 3.67 \\
\hline Toplam & 109 & 100 \\
\hline
\end{tabular}


yorum. Çünkü 4 yıldır teorik bilgileri zaten edindik. Önemli olan gerçek bir sınıfta, gerçek öğrencilerle birlikte yaşanmışlık kazanmak

k.100: Kesinlikle uygulama boyutunun daha çok geliştirdiğini düşünüyorum. Çünkü öğrencilerin bazen ne yapacakları belli olmuyor, küçük çocuklar büyük sürprizler yapabiliyorlar. Bunları görmemiz, canlı tecrübe etmemiz, öğretmeni birebir işin içinde gözlemlememiz bize çok şey kattı. Yeri geldi eksik olduğumuz noktada sınıf öğretmeni bize fikirler verdi. İleride mesleğimizi yaparken bu yaşadığımız staj deneyimlerinden fazlasıyla yararlanacağız. Teorik bilgi biraz havada kalıyor ne yazık ki.

k.103: Kesinlikle uygulama. Teori hem yüzeysel hem havada kalıyor. Uygulamada çocuklarla iç içe olmak bambaşka bir dünya.Asıl beceriyi geliştiren, birikim yapmamızı sağlayan onlarla iletişim içinde olmak.

Öğretmen adaylarının görüşlerinde ifade ettikleri gibi, öğretmenlik uygulamasında geliştiren boyutun uygulama boyutu olduğunu belirttikleri görülmektedir.

Araştırmanın bir sonraki bulgusunda öğretmen adaylarının uzaktan eğitimde öğretmenlik uygulamasının olumlu yanlarına ilişkin belirttikleri görüşler verilmiştir.

Öğretmenlik uygulamasının uzaktan eğitimde yapılması konusunda öğretmen adaylarının en çok olumlu bir yanı yoktur alt temasına yönelik görüş belirttikleri Tablo 11'de görülmektedir. Öğretmen adayları (f:44) bu uygulamanın olumlu bir yanının olmadığını düşünmektedirler. Katılımcılardan 23'ü ise bu uygulamaların bilgi birikimi sağladığını söylemişlerdir. 15 öğretmen adayı ise zamandan tasarruf olduğunu belirtmiştir. Öğretmenlik uygulamasının uzaktan eğitimde olmasının olumlu yanları temasına ilişkin görüş bildiren katılımcıların görüşlerinden bazıları şu şekildedir; k.4: Bana göre öğretmenlik uygulamasının uzaktan eğitimle yağılmasının hiöbir olumlu yanı yok. Çünkü birebir yaşayıp öğrenme olmadan deneyimlemeden bu işi kavramak oldukça zor.

k.39: Son sinıfların mezuniyetinin ertelenmemesi ve onların mağdur edilmemesi.

k.40: Olumlu yönü olduğunu çok düşünmüyorum. Çünkü ben öğrencilerle birlikte olup sınıfta ders anlatmak isterdim. Şuan tek olumlu olarak uygulama öğretim elemanının bize makale okutmasını görüyorum. Onun sayesinde verdiği konularda yapılan çalışmaları görüyoruz.

k.53: Hiç yapılmamasındansa uzaktan yapılması daha iyidir. En azından öğretmenlikle ilgili önemli konularda araştırmalar yapıp raporlar yazıyoruz. Sonra bunlar üzerine konuşuyoruz. Ama tabi ki de öğrencilerle yaptığımız derslerin yeri çok ayrı.

k.77: Olumlu yönü olarak baktığımızda uygulamanın bilgi kısminda bilmemiz gereken şeyleri öğreniyoruz ayrıca uygulama öğretmenimizle nasıl daha iyi bir sınıf ortamı nasıl daha iyi bir öğretim yapacă̆ımız hakkında fikir alışverişi yapıyoruz.

k.84: Böylece öğretmenlik hayatına atıldığımızda hazırlamamız gereken evrak işlerini öğrenmiş olduk.

k.98: Bu uygulama ile akademik araştırma yapma konusunda daha tecrübeli hale geldiğimi düşünüyorum. Ayrıca uzaktan eğitim konusunda aklımda olan birçok soru işaretini kendi adıma gidermiş oldum.

k.104: İşin teorik kısmına daha çok yönelip bilgi bazında ve araştırma bazında artıları var.

k.105: sabah okula gitmek için hazırlanmakla vakit kaybetmiyoruz.

Öğretmenlik uygulamasının uzaktan eğitimle yapılma-

Tablo 11. ÖU'nın UE'de Olumlu Yanları Temasına İlişkin Alt Temaların Yüzde ve Frekans Dağılımları

\begin{tabular}{lcc}
\hline ÖU'nın UE'de Olumlu Yanları & f & Yüzde \\
\hline Olumlu Bir Yanı Yok & 44 & 40.37 \\
Bilgi Birikimi Sağlar & 23 & 21.10 \\
Ödev, Rapor ve Araştırmaya Olanak Sağlar & 22 & 20.18 \\
Zamandan Tasarruf & 15 & 13.76 \\
Diğer & 11 & 10.09 \\
Mezuniyet Durumu & 5 & 4.59 \\
\hline Toplam & 109 & 100 \\
\hline
\end{tabular}


sına ilişkin, katılımcılar olumlu bir yan bulamadıklarını ifade etmiş ancak görüş bildiren bazı öğretmenler evrak işlerinin öğrenilmesi ya da zaman tasarrufu gibi olumlu birkaç yana değinmiştir.

Araştırmanın bir sonraki bulgusunda öğretmen adaylarının uzaktan eğitimde öğretmenlik uygulamasının olumsuz yanlarına ilişkin belirttikleri görüşler verilmiştir.

Öğretmenlik uygulamasının uzaktan eğitimde yapılmasının olumsuz yönleri konusunda öğretmen adaylarının en çok deneyimsizlik alt temasına yönelik görüş belirttikleri tespit edilmektedir. 54 öğretmen adayı bu uygulamada etkileşim olmamasının olumsuz olduğunu düşünmektedir. Katılımcılardan 10'u ise uzaktan eğitimde öğretmenlik uygulamasını verimsiz olarak değerlendirmiştir. Öğretmenlik uygulamasının uzaktan eğitimde olmasının olumsuz yanları temasına ilişkin görüş bildiren katılımcıların görüşlerinden bazıları şu şekildedir;

k.13: Olumsuz yönü mesleğimizin en değerli parçası olan öğrencilerimizden, çocuklarımızdan uzak kalmamız. Özellikle bu dönem daha yeni yeni birbirimizi tanıyorken ayrıldı yollarımız. Bizim için stajda ne kadar uygulama yaparsak kazanımımız o kadar fazla olacakt1. Şimdi ise tecrübe edeceğimiz birçok şeyden mahrum kalmış biçimde mezun olacağız.

k.40: Öğretmenlik uygulamasının uzaktan eğitimle yapılmasının olumsuz yönü öğrencilerle birlikte olup ders anlatmıyoruz. Kendimizi sınıfta bir öğretmen gibi hissedemiyoruz. Kazanımlara ilişkin konu anlatmamız yarım kalıyor. Orada ürettiğimiz fikirler bize öğretmen olduğumuz zaman sınıfımızda uygulamak için örnek oluyordu. Şu an konulara nasıl işleyeceğimize ilişkin örnekler göremiyoruz

k.46: Yaparak yaşayarak öğrenilmesi gereken bir durumu teori olarak görüyoruz. Bu süreçte öğretmenlerimi- zin tecrübelerinden faydalanamıyoruz. Çocuklarla etkileşim içinde değiliz ileride bir etkinlik tasarladığımız zaman bu çocuklarda nasıl bir etkiye sahip olucak onu göremiyoruz.

k.53: Öğrencilerimizden uzak kalmamız ilk sırada geliyor. Çünkü tam onlarla kaynaşmaya başladığımız, öğrencilerimizi tanımaya, özelliklerini bilmeye başladığ1mız bir zamand. Birbirimize alışmış ve kaynaşmıştık. Şu an birbirimizden uzak kaldık. Teorik dersler uygulamalı derslerin yerini tutmuyor. Tecrübe eksikliğimiz oluyor.

k.57: Birincisi mesleğimizi yeterince öğrenemiyoruz, teorik olarak öğrenmek mümkün değil. Bunun farkına ilk staj günümde varmıştım. İkincisi bizim en büyük tamamlayıcımız olan öğrenci eksik. Ben öğrenci olmadan bir öğretmenin, sadece teorik yazılarla öğretmen olabileceğine inanmıyorum. Öğretmenlik uygulaması her açıdan bize çok yararlıydı. Şimdi yokluğunu üzülerek hissediyoruz.

k.80: öğretmenlik mesleğine ait bir çok yeterliliği sınıfta öğrencilerle tecrübe kazanarak elde edeceğimizi düşünüyorum. Uzaktan eğitimle öğretim süreci ve Sınıf yönetimi gibi konularda yeterlilik kazanamayız.

k.85: Öğretmenlik uygulaması derslerimizde yeterliliklerimizi ve eksikliklerimizi görüp mesleki anlamda kendimizi geliştiriyorduk. Bu ders aslında bize mesleğimizin ne kadar güzel bir meslek olduğunu yaşayarak görmemizi sağlıyordu. Uzaktan eğitimle bize bu fırsatları sunamiyor.

k.91: Şu an yaptığımız şeyi öğretmenlik uygulaması olarak görmüyorum zaten. Sadece teorik olarak bazı konuları konuşuyoruz. Uygulama bambaşka bir mevzu. Yaşayarak öğrenme çok daha kalıcı ve kendi kendimize tecrübe kazanıyorduk istemesek de.

k.98: Bu durum bizim için çok büyük dezavantaj tabi

Tablo 12. ÖU'nın UE'de Olumsuz Yanları Temasına İlişkin Alt Temaların Yüzde ve Frekans Dağılımları

\begin{tabular}{lcc}
\hline ÖU'nın UE’de Olumsuz Yanları & f & Yüzde \\
\hline Deneyimsizlik & 70 & 64.22 \\
Etkileşim Yok & 54 & 49.54 \\
S Sinıftan ve Öğrencilerden Uzak & 41 & 37.61 \\
$\square \quad$ Artı ve Eksi Yönler Belirlenemez & 12 & 11.01 \\
Geri Dönüt Alınamaz & 10 & 9.17 \\
Verimsiz Süreç & 33 & 30.28 \\
Olumsuz Yanı Yok & 1 & 0.92 \\
\hline Toplam & 109 & 100 \\
\hline
\end{tabular}


ki. Gerçek sınıflarda öğrencilerle yaşayacağımız tecrübeler sadece raporlarla araştırma ödevleri haline döndüğü için ilerde tecrübe eksikliği yaşayacağımızı düşünüyorum. Başka derslerin telafisi yapılıyor ama öğretmenlik dersinin teorik olarak ilerlemesi çok talihsiz bir durum

k.106: Tamamen olumsuz olduğunu düşünüyorum. Uygulamada sadece ders anlatmıyorduk. Birçok öğrenciyi de gözleme şansımız oluyordu. Onlarla iletişim kuruyorduk. Sınıfa girdiğimizde her şey o akış içerisinde gelişiyordu. Bunların hiçbirini uzaktan eğitimle sağlayamadik.

Katılımcılar, öğretmenlik uygulamasının uzaktan eğitimle yapılmasına yönelik belirttikleri görüşlerde, tecrübe açısından büyük eksiklik olacağından ve sınıfta öğrenciler ile ya da öğretmenler ile etkileşimin az olmasının ileride olumsuzluklar yaratacağından bahsetmişlerdir.

Araştırmanın bir sonraki bulgusunda öğretmen adaylarının öğretmenlik uygulamasının içeriğine ilişkin belirttikleri görüşler verilmiştir.

Öğretmenlik uygulamasının içeriği temasına yönelik görüş belirten öğretmen adaylarının 48'i uygulama boyutundan, 46'sı süreç boyutundan ve 45'i ise değerlendirme ve not verme boyutundan bahsetmiştir. "Öğretmen adaylarına öğretmenli uygulaması sizce nasıl olmalıdır?" sorusu sorulmuş ve bunu uygulama boyutuyla ilişkilendiren katılımcıların 25'i ders içeriğinin ve uygulamanın genişletilmesinden bahsettiği belirlenmiştir. Öğretmenlik uygulamasının içeriği temasına ilişkin görüş bildirerek, bunu ders planı hazırlamanın sürece dahil edilmesi yönünde görüşlerden bazıları şu șekildedir k.12: Aynı uygulamada hazırlanıldığı gibi bir etkinlik planı gene hazırlanmalı ve bu plan uzaktan eğitimle olsa dahi uygulama öğretmenine planı sınıfta yaşıyormuş gibi anlatmalı. Daha sonrasında bu etkinlik planının sınıfta uygulanıp uygulanamayacağına karar verilmeli ve uygulama öğretmeni etkinliğin hayata geçirdiği aşamada öğrenciyi gözlemleyerek ders sonunda ona eksiklerini söylemeli.

k.31: -Öğretmen konuları vermeli biz planlarımızı etkinliklerimizi hazırlayıp sunmalıyız. Daha sonra öğretmen ve diğer arkadaşlarımız beraber değerlendirme yapmalı. En son da öğretmenimiz notlandırma yapmalı

k.33: Öncelikle öğretmenlik uygulaması dersinin uzaktan eğitime geçmesi makale incelemek olarak algılanmiş ve her hafta makale inceler olduk. Bu son derece yanlış. Bunun yerine öğrencilerle konuşulup ortak bir karara varılabilir. Bu süreçte öğrencileri yok saymak söz konusu olamaz. Çünkü mezun olacak olan bizler mezun olup atandığımızda mağdur olacak kişileriz. Bu uygulama haftalık etkinlik planı hazırlama günlük eğitim akışı hazırlama aylık eğitim planı hazırlama şeklinde olabilir.

k.79: Öğretmenlik uygulamasında 11 makale inceleyeceğiz. Makalede problem durumu, araştırmanın önemi, bulgular, tartışma ve sonuç gibi bölümleri inceleyeceğiz. Bunlar yerine ders planı yapmamız daha iyi olurdu. Gidemediğimiz her hafta için kendi seçtiğimiz konularda ders planı yapardık ve hocamıza atardık o da bizi değerlendirirdi. Eksiklerimizi söylerdi. Eksiklerimizi tamamlayıp tekrar atabilirdik. Tıpkı gerçekten staja gittiğimizde yaptığımız gibi. Hem bizim için daha verimli olurdu. Kendimizi geliştirirdik. Ve ileride o ders planlarını kendi sınıfımızda kullanabilirdik. Ma-

Tablo 12. ÖU'nın İçeriği Temasına İlişkin Alt Temaların Yüzde ve Frekans Dağılımları

\begin{tabular}{ccc}
\hline Öğretmenlik Uygulamasının İçeriği & f & Yüzde \\
\hline Uygulama Boyutu & 48 & 44.04 \\
$\square \quad$ Ders İçeriği ve Uygulamalar Genişletilmeli & 25 & 22.94 \\
$\square \quad$ Gerçeklere Hazırlamalı & 10 & 9.17 \\
$\square \quad$ Her Sınıf Düzeyinde Olmalı & 7 & 6.42 \\
Süreç Boyutu & 46 & 42.20 \\
$\square \quad$ Ders Planı Hazırlama Sürece Dahil Edilmeli & 21 & 19.27 \\
$\square \quad$ Öğretmen Adayı Süreçte Aktif Olmalı & 16 & 14.68 \\
\hline$\square$ & Dersler Tartışmaya Açı ve Etkileşimli Olmalı & 14.68 \\
Değerlendirme ve Not Verme Boyutu & 16 & 41.28 \\
$\square \quad$ Süreç Odaklı & 45 & 21.10 \\
$\square \quad$ Not Verirken Adil Olunmalı & 23 & 8.26 \\
$\square \quad$ Birden Fazla Hoca Katılmalı & 9 & 5.50 \\
$\square \quad$ Öğrenci Görüşleri Katılmalı & 6 & 4.59 \\
$\square \quad$ Eksiklikleri Tamamlamaya Yönelik Bir Değerlendirme & 5 & 2.75 \\
\hline Toplam & 3 & 100 \\
\hline
\end{tabular}


kale incelemenin aynı etkiyi yaratacağını düşünmüyorum

k.93: Etkinlik planları istenebilir, onları sunmaları istenebilir daha yararlı olacaktır çünkü ders içeriğiyle ilgili olması gerektiğini düşünüyorum. Notlar da etkinlik planlarına göre verilebilir ya da etkinlik planlarının sunumlarına göre.

Öğretmen adayları belirttikleri görüşlerde, sınıf içerisinden ders planı hazırlayarak bu dersin tartışmalı bir şekilde, etkileşim içerisinde geçmesinin ders içeriğini zenginleştireceğini belirttikleri görülmektedir.

\section{TARTIŞMA, SONUÇ VE ÖNERİLER}

$\mathrm{Bu}$ araştırmada öğretmen adaylarının pandemi sürecindeki uzaktan eğitim uygulamalarına ve öğretmenlik uygulamasına ilişkin görüşleri alınmış ve oluşturulan 11 tema ve alt temalar altında yorumlanmıştır. Bu bölümde, elde edilen bulgular literatürdeki araştırmalar ile ilişkilendirilerek tartışılmıştır.

Araştırmada, uzaktan eğitim uygulamalarının etkili olma durumuna ilişkin olarak oluşturulan tema ve alt temalar doğrultusunda öğretmen adaylarına göre pandemi döneminde uzaktan eğitim uygulamalarının yeterli olmadığı sonucuna ulaşılmıştır. Öğretmen adayları uzaktan eğitimin etkisiz olmasının nedenlerini ise en çok derslerin işleniş şekli ve öğretim elemanlarından kaynaklı yetersizlikler ile ilişkilendirmişlerdir. Araştırma sonuçları ile sürecin etkisiz ve verimsiz geçmesi yönünden, Başaran ve diğerleri'nin (2020) pandemi sürecinin getirisi olan uzaktan eğitimin etkililiği ile ilgi yaptığı çalışmada, sürecin eksik ve yetersiz kaldığ durumların da olduğu, öğrencilerin uzaktan eğitim sürecinde derslerden tam anlamıla verim alamadıklarını dile getirmeleri sonuçları ile paralellik göstermektedir.

Öğretmen adayları uzaktan eğitimin olumlu yönlerine ilişkin bildirdikleri görüşlerde en çok zamandan tasarruf ettiklerini belirttikleri ve bunu ders kayıtlarını tekrar izleme ile mümkün olduğunu ifade ettikleri görülmüştür. Derslerin kaydedilerek erişilebilir olmasının bu dönemde olumlu değerlendirilmesi boyutu ile Serçemeli ve Kurnaz'ın (2020) araştırma sonuçları benzerlik göstermektedir. Katılımcılar evde olmanın, okula gitmekten ziyade daha az zaman harcattığını ve diğer etkinliklere zaman kalmasının olumlu olduğunu ifade etmişlerdir. Bununla birlikle bu dönemde eğitimin sürekliliğinin sağlanmasının da uzaktan eğitimin olumlu yanlarından olduğu sonucuna ulaşılmıştır.
Araştırmada ulaşılan diğer bir sonuç, pandemi döneminde geçilen acil uzaktan eğitim uygulamalarının olumsuz yanının fırsat eşitliğinin ve herkesin interneti erişimi olamayacağı, bundan dolayı da uzaktan eğitimde olumsuzlar yaşandığına ilişkindir. Öğretmen adayları interneti olmayan arkadaşlarının derslere giremediklerini ya da dersteki internet sorunları yüzünden derslerin verimsiz olduğunu ifade etmiştir. Kürtüncü ve Kurt'da (2020), hemşirelik bölümü öğrencileri ile yaptıkları araştırmada imkânı kısıtlı öğrencilerin herkesle eşit koşullarda derslerini takip edemediği sonucuna ulaşılmışlardır. Bu durumda üniversite öğrencilerinin fırsat eşitsizliğiyle karşı karşıya olma durumları araştırma sonuçlarıyla benzerlik gösterdiği söylenebilir. Sahu'ya (2020) göre öğrencilerin en çok değindikleri konu üniversitenin uzaktan eğitim alt yapısının yetersiz olmasıyla, birçok öğrencinin internet erişiminde problem ile karşılaşması, derslerini takip edememeleri ve derslerden verim alamamalarına ilişkindir. Bu bulgu da araştırma sonuçlarına paralellik göstermektedir. Katılımcıların bir kısmı pandemi döneminin olumsuz yanlarını iletişimsizliğin ortaya çıkması, sınıf ve okuldan uzak olmak olarak değerlendirmişlerdir. Bulgulara göre bu sürecin öğrencilere özgürlük sunduğu ve derslere keyfi girmemelerin arttığı ve az katılımlı derslerin verimsiz geçtiği sonucuna ulaşılmıştır. Öğrencilerin ödev ve sınavlara yönelik bahaneleri çoğalmış ve bu durum uzaktan eğitim uygulamalarında olumsuzluk olarak görülmüştür.

Öğretmen adaylarının çoğuna göre salgın sürecinde internet ve derse bağlanma, dersi kesintisiz şekilde sürdürme konusunda eksiklikler görülmektedir. Uygulama gerektiren derslerin yapılamaması ve sürece hazırlıksız girmenin de bu süreçte eksiklik olarak değerlendirildiği ifade edilmiştir. İnternet erişiminin bir sorun teşkil etmesi konusunda, Çevik ve Bakioğlu (2020), pandemi sürecinde fen bilgisi öğretmenlerinin uzaktan eğitime ilişkin görüşlerini inceledikleri çalışmalarında, öğretmenlerin, uzaktan eğitimde yaşadıkları en büyük problemlerinin bilgisayarla ilgili olarak yazılım/donanım problemleri; internet bağlantısı sorunları olduğu sonucuna ulaşmışlardır. Araştırma bulguları bu açıdan paralellik göstermektedir. Karahan, Bozan ve Akçay'ın (2020) sınıf öğretmeni adayları ile yaptığı çalışma sonuçları ile bu süreçte bir sorun yaratması sonucu paralellik göstermektedir. Lau ve diğerleri (2020) yaptıkları araştırmada, Çin'de kırsal alanlardaki öğrencilerin uzaktan eğitim için gerekli donanıma ya da bağlantıya sahip olmadıkları sonucu ile benzer 
sonuçlar elde edilmiştir. Öğretmen adaylarının, iletişimsizliği ve sınıf ortamından uzak olmayı eksiklik olarak değerlendirmeleri ile Başaran ve diğ.'nin (2020) uzaktan eğitimin en önemli eksikliği ise okul ortamının sonucu olarak eğitim ve öğretim ruhunu veremiyor, bu durumun da sanal ortamdan eğitim faaliyetlerini güç hale getiriyor şeklindeki araştırma sonuçları paralellik göstermektedir.

Araştırmada elde edilen bulgular yorumlandığında, uzaktan eğitim sürecinde öğretim elemanları öğretmen adayları tarafından yeterli bulunmuştur. Öğretmen adaylarının görüşlerine göre bu süreçte zaten çok fazla zorluk vardır ve öğretim elemanları ellerinden geleni yaparak eğitimin devam etmesini sağlamaktadırlar. Öğretmen adaylarından alınan görüşler doğrultusunda öğretim elemanlarının bu süreci ellerinde olanın en iyisiyle idare etmeye çalıştıkları sonucuna ulaşılmıştır. Bu sonuçlar ile Karahan, Bozan ve Akçay’ın (2020) araştırma sonuçları sınıf öğretmeni adaylarının öğretim elemanları teknolojik açıdan yetersiz bulmaları yönünden farklılaşmaktadır. Benzer şekilde Karadağ ve Yücel (2020) sosyal bilimler alanında görev yapan öğretim elemanlarının teknoloji kullanma yeterliliklerinin düşük olduğunu belirtmeleri ile farklılık göstermektedir.

Temeli uygulama olan öğretmenlik uygulamasının, salgon döneminde uzaktan olarak yapılmasının tecrübe eksikliğine neden olduğunu ve uygulama yapmanın yerini tutamayacağ 1 ifade edilmiştir. Öğretmen adayları öğretmenlik uygulamasında deneyimi ilk sıraya koymuş ve uzaktan eğitimde eksiklik olarak değerlendirmişlerdir. Bulgular sonucunda bu durumun bir mecburiyet olduğunu ve mutlaka telafi edilmesi gerektiği şeklinde sonuçlar elde edilmiştir. Serçemeli ve Kurnaz'ın (2020) araştırma sonuçlarında muhasebe öğrencilerinin pandemi sonrasında tekrardan etkileşimli bir şekilde dersleri okulda almak istemeleri sonucu ile araştırma sonuçları paraleldir.

Öğretmenlik uygulamasının geliştiren boyutuna yönelik olarak öğretmen adayları, en çok uygulama boyutundan bahsedildiği sonucuna ulaşılmıştır. Öğretmen adayları uygulama boyutunun tecrübe, öğrencilerle bir arada olma ve geri bildirimler ile gelişim sağlama gibi yönlerinden dolayı teorinin önüne geçemeyeceğini belirtmişlerdir. Öğrenciler ile ayı ortamda olmak ve onların davranışlarını deneyimleyerek zihin süzgecinden geçirmenin ve sonuçlara varmanın teorik olarak sağlanamayacağını düşünen öğretmen adayları uzaktan eğitimde sınıf öğretmenlerinden dönüt alamadıkları için gelişim sağlayamadıklarını belirtmişlerdir.

Elde edilen bulgular sonucunda uzaktan eğitimde öğretmenlik uygulamasının katılımcıların çoğuna göre olumlu bir yanının olmadığı sonucuna ulaşılmıştır. Teorinin uygulamanın yerini tutmayacağını düşünen öğretmen adayları, uzaktan eğitimde öğretmenlik uygulamasına ilişkin olumlu bir değerlendirme yapmamıştır. Katılımcıların bir kısmı uygulama yerine verilen makale inceleme ödevlerini ve raporları gelişim olarak değerlendirmiş ve olumlu varsaymışlardır. Eğitim fakültesi 4. Sınıf öğrencilerinden bazıları ise mezun olmak için staj yerine yalnızca teorik boyutta işlenen derslerin kabul edilmesinin mezun olmaları açısından olumlu olarak değerlendirmiştir. Bu sonuç, Kürtüncü ve Kurt'un (2020), araştırmalarında son sınıf hemşirelik öğrencilerinin özellikle dönem kaybı ve mezun olamamaya neden olabileceğini düşündükleri sonucu ile benzerdir.

Salgın döneminde öğretmenlik uygulamasının uzaktan yapılmasına ilişkin olarak öğretmen adaylarının görüşlerine göre deneyimsizliğin en önemli olumsuzluklardan biri olduğuna, sınıftan ve öğrencilerden uzak olmanın, kendi artı ve eksi yönlerini görememenin de bu süreçteki olumsuzluklardan olduğu sonucuna ulaşılmıştır.

Öğretmenlik uygulamasının içeriği temasına ilişkin bulgulara göre, öğretmen adaylarının bu süreci uygulama, süreç ve değerlendirme ve not verme boyutunda değerlendirdikleri sonucuna ulaşılmıştır. Uygulama boyutunda ders içeriğinin daha geniş ve etkileşimli olmasını, uygulamanin daha fazla yer almasının gerekliliğini belirtmişlerdir. Süreç boyutunda ise haftalık ve günlük ders planları ile sürecin daha aktif olacağını, derste bu planların tartışılmasının ve öğrenci merkezli geçmesinin daha iyi olacağını düşünmektedirler. Notların adil şekilde verilmesi gerektiği ve tüm süreci kapsayarak, gerekirse öğrenci ve staj öğretmeni görüşlerine de başvurulması gerektiğini belirttikleri sonucuna ulaşılmıştır.

Araştırma sonuçlarına yönelik olarak geliştirilen öneriler şu şekilde sıralanabilir;

Uzaktan eğitimde işlenen derslerin, öğretim yöntem ve teknikleri gözden geçirilerek, ders işleniş şeklinde bir düzenlemeye gidilebilir ve bu sürecin daha etkili kılınması sağlanabilir.

Fırsat eşitliğinin sağlanması açısından, öğrencilerin 
derse erişimlerinin kolaylaştırılması, internet, alt yapı imkanlarının geliştirilmesi gerekmektedir. Öğrencilerin derse yönelik devamlılıklarının kontrol edilmesi ve etkili bir ders ortamının oluşturulması için derslere katılımın arttırılması sağlanmalıdır.

Uzaktan eğitimde yürütülen uygulamalı derslerin dönem sonunda telafilerinin ikan dahilinde sağlanabilir. Öğrenciler deneyimsiz bir şekilde işe başlamaktan korktukları için uygulamalar yapılabilir. Ders içerikleri daha çok uygulamaya dönük ve öğrencinin aktif olduğu şekilde planlanabilir. Bunun yanında öğretmenlik uygulamasında ders planı hazırla sürecine önem verilebilir ve dersler tartışmalı, öğrenci fikirlerine açık hale getirilebilir.

Yapılacak yeni araştırmalarda, uzaktan eğitimin olumsuz yanları sosyo-ekonomik durumlar, yaşanılan yerin koşulları ve maddi gelir gibi değişkenler dahilinde de incelenerek araştırma genişletilebilir. Araştırma verileri ölçek, görüşme gibi farklı veri toplama yöntemleri ile toplanarak verilerde çeşitlilik sağlanabilir. Birbirini destekler nitelikte bulgular yorumlanabilir.

\section{KAYNAKÇA}

AGNOLETTO, R., \& QUEIROZ, V. (2020). COVID-19 and the challenges in Education. Brazil: Universidade de São Paulo.

BAKİĞLU, B., \& ÇEVIK, M. (2020). COVID-19 Pandemisi Sürecinde Fen Bilimleri Öğretmenlerinin Uzaktan Eğitime İlişkin Görüşleri. Electronic Turkish Studies, 15(4).

BAŞARAN, M., DOĞAN, E., KARAOĞLU, E., \& ŞAHIN, E. (2020). Koronavirüs (Covı-19) Pandemi Sürecinin Getirisi Olan Uzaktan Eğitimin Etkililiği Üzerine Bir Çalışma. Academia Eğitim Araştırmaları Dergisi, 5(2), 179-209.

BOZKURT, A. (2020). Koronavirüs (Covid-19) pandemi süreci ve pandemi sonrası dünyada eğitime yönelik değerlendirmeler: Yeni normal ve yeni eğitim paradigması. Açıköğretim Uygulamaları ve Araştırmaları Dergisi, 6(3), $112-142$.

BÜYÜKÖZTÜRK. Ş. (2013). Sosyal bilimler için veri analizi el kitabı. Pegem Yayınevi, Ankara.

CAN, E. (2020). Coronavirüs (Covid-19) pandemisi ve pedagojik yansımaları: Türkiye'de açık ve uzaktan eğitim uygulamaları. Açık öğretim Uygulamaları ve Araştırmaları Dergisi, 6(2), 11-53.

COECKELBERGH, M. (2020). The postdigital in pandemic times: A comment on the Covid-19 crisis and its political epistemologies. Postdigital Science and Education, 2(3), 547-550.

CRESWELL, J. W. (2011). Controversies in mixed methods research. The Sage handbook of qualitative research, 4, 269-284.

ÇAKIN, M., \& AKYAVUZ, E. K. (2020). Covid-19 süreci ve eğitime yansıması: öğretmen görüşlerinin incelenmesi. International Journal of Social Sciences and Education Research, 6(2), 165-186.

DANIEL, J. (2020). Education and the COVID-19 pandemic. Prospects, 49(1), 91-96.
ERKUT, E. (2020). Covid-19 sonrası yükseköğretim. Yükseköğretim Dergisi, 10(2), 125-133.

GEWIN, V. (2020). Five tips for moving teaching online as COVID-19 takes hold. Nature, 580(7802), 295-296.3

GIANNINI, S. \& LEWIS, G.S.(2020). Three ways to plan for equity during the coronavirus schoolclosures. https://gemreportunesco.wordpress. com/2020/03/25/three-ways-to-plan-forequity-during-thecoronavirus-school-closures/web,Erişim Tarihi: 16.03.2021

KARADAĞ, E. ve YÜCEL, C. (2020). Yeni Tip Koronavirüs Pandemisi Döneminde Üniversitelerde Uzaktan Eğitim: Lisans Öğrencileri Kapsamında Bir Değerlendirme Çalışması. Yükseköğretim Dergisi, 1-12. https://doi.org/10.2399/yod.20.730688

KARAHAN, E., BOZAN, M. A., \& AKÇAY, A. O. (2020). Sınıf Öğretmenliği Lisans Öğrencilerinin Pandemi Sürecindeki Çevrim İçi Öğrenme Deneyimlerinin İncelenmesi. Electronic Turkish Studies, 15(4).

KESKIN, M., ÖZER KAYA, D. (2020). COVID-19 sürecinde öğrencilerin web tabanlı uzaktan eğitime yönelik geri bildirimlerinin değerlendirilmesi. İzmir Kâtip Çelebi Üniversitesi Sağlık Bilimleri Fakültesi Dergisi, 5(2), 5967.

KÜRTÜNCÜ, M., \& KURT, A. (2020). COVID-19 pandemisi döneminde hemşirelik öğrencilerinin uzaktan eğitim konusunda yaşadıkları sorunlar. $A v$ rasya Sosyal ve Ekonomi Araştırmaları Dergisi, 7(5), 66-77.

LAU, J., YANG, B. VE DASGUPTA, R. (2020). Will the coronavirus make online education go viral? timeshighereducation.com: https://www. timeshighereducation.com/features/ will- coronavirus-make-online-education-go-viral

LAU, J., YANG, B., \& DASGUPTA, R. (2020). Will the coronavirus make online education go viral?

Merriam, S.B. (2018). Nitel araştırma desen ve uygulama için bir rehber. (Çev. Selahattin Turan). Ankara: Nobel Yayınevi.

MiKS, J., \& MCILWAINE, J. (2020). Keeping the world's children learning through COVID-19. Acesso em, 6(05).

MILES, M, B., \& HUBERMAN, A. M. (1994). Qualitative data analysis: An expanded Sourcebook. (2nd ed). Thousand Oaks, CA: Sage.

SAHU, P. (2020). Closure of universities due to coronavirus disease 2019 (COVID-19): Impact on education and mental health of students and academic staff. Cureus, 2019(4), 4-9. http://doi.org/10.7759/cureus.7541

SERÇEMELİ, M, KURNAZ, E. (2020). Covid-19 pandemi döneminde ögrencilerin uzaktan eğitim ve uzaktan muhasebe eğitimine yönelik bakış açıları üzerine bir araştırma. Uluslararası Sosyal Bilimler Akademik Araştırmalar Dergisi, 4 (1), 40-53. retrieved from https://dergipark.org.tr/en/pub/ utsobilder/issue/55152/741358

Türk Dil Kurumu (TDK) (2021). Bilim ve sanat terimleri sözlüğü. Erişim adresi: https://sozluk.gov.tr/,Erişim Tarihi: 21.05.2021

UNESCO. (2020. School closures caused by Coronavirus (Covid-19). UNESCO. Erişim adresi: https://en.unesco.org/covid19/educationresponse ,Erişim Tarihi: 26.05.2021

World Health Organization (WHO) (2021). Q\&A on coronaviruses (COVID-19). Erişim adresi: https://www.who.int/health-topics/coronavirus\#tab=tab_1 (Erişim Tarihi: 26.05.2021)

YILDIRIM, A. VE ŞIMŞEK, H. (2018). Sosyal bilimlerde nitel araştırma yöntemleri. Ankara: Seçkin Yayınevi.

Yüksek Öğretim Kurulu (YÖK) (2020). Basın açıklaması, https://www.yok. gov.tr/Sayfalar/Haberler/2020/, Erişim tarihi: 29.03.2020. 